\title{
Czy Alpy są dla turystyki? 150 lat krytyki ruchu turystycznego
}

\author{
https://doi.org/10.19195/2084-4107.14.7
}

Określenie „turysta” pojawiło się w późnym XVIII wieku w języku angielskim, a w połowie XIX wieku zadomowiło się również w innych językach europejskich. Odpowiedni sektor nazywano w języku niemieckim z początku Fremdenverkehr (dosłownie ,ruch obcych”). Od lat siedemdziesiątych XX wieku standardem stało się neutralne, międzynarodowe wyrażenie Tourismus ${ }^{1}$. Ta związana z mobilnością branża nie jest dziedziną gospodarki jak każda inna. Przybywający z zewnątrz nabywcy usług mają być zarazem ,gośćmi”, i to nie tylko określonego przedsiębiorstwa turystycznego, ale często całej okolicy. Poruszają się oni w otoczeniu stworzonym przez innych i mogą sobie niemalże przywłaszczać przestrzeń publiczną przez swoje śmiałe, masowe występowanie. Od niedawna w użyciu jest słowo Overtourism. Wskazuje ono na obciążenia dotykające mieszkańców w związku z napływającym potokiem odwiedzających oraz powstający w ten sposób potencjał konfliktowy².

Alpy należą do terenów, na których turystyka już w XIX wieku stała się przemysłem. Szczególnie po 1850 roku liczba turystów w tych górach — z początku przede wszystkim w Szwajcarii — wzrosła w znaczący sposób. Nastąpiła szybka rozbudowa infrastruktury $\mathrm{w}$ formie nowoczesnych środków transportu, miejsc noclegowych oraz wszelkiej innej oferty. Turystyka stała się indykatorem i faktorem mieszczańskiego „postępu”. Jednocześnie odezwały się głosy krytykujące taki rozwój. Aby zastanowić się nad tymi krytycznymi punktami widzenia w dłuższym czasie, wybrano w niniejszym artykule trzy przykłady z różnych obszarów, okresów i regionów. Pierwsza część poświęcona jest literaturze, a dokładniej opublikowanemu po raz pierwszy w roku 1880 satyrycznemu opisowi podróży po Szwajcarii. Tematem drugiej części jest nauka, przede wszystkim na podstawie pism pewnej francuskiej geografki z lat 1956-1971. Trzecia część traktuje o polityce turystycznej ostatnich lat w alpejskiej wiosce w Austrii. Odpowiedź na pytanie „Do kogo należą góry?" aktorzy wydarzeń mają więc dać w tym artykule sami. W podsumowaniu pokusimy się o przedstawienie omawianych aspektów w szerszym kontekście.

\section{Literatura: Mark Twain, 1878-1880}

Humorystyczno-satyryczne sprawozdanie z podróży A Tramp Abroad amerykańskiego autora Marka Twaina (właściwie Samuel Langhorn Clemens) zostało wydane w 1880 roku i szybko osiągnęło sukces. Pierwsza niemiecka edycja uka-

1 Za: Google Ngram (dostęp: 28.07.2019). W tym artykule cytaty w innych językach zostały przetłumaczone na język niemiecki, a następnie polski. Za krytyczną lekturę i informacje dziękuję Andreasowi Bürgi, Clá Rietsch i Anne Sgard.

2 E. Aschwanden, Overtourism wird zum Konfliktfeld in der Schweiz, „Neue Zürcher Zeitung” 24.05.2019.

Góry — Literatura - Kultura 14, 2020

(C) for this edition by CNS 
zała się na rynku w roku 1892 pod tytułem Bummel durch Europa. Opis zawiera wiele fikcyjnych elementów, ale opiera się na podróży, którą autor przedsięwziął w poprzedzających latach 1878 i 1879 z zamiarem napisania swojej drugiej travel book. Podróż rozpoczęła się w Nowym Jorku, skąd autor udał się do Hamburga, potem do południowych Niemiec, Szwajcarii, Francji, Włoch i z powrotem. Alpejska część podróży prowadziła z Lucerny przez Wyżynę Berneńską i Wallis do Chamonix i Genewy. Obejmuje ona rozdziały 25-47 z pięćdziesięciu zawartych w książce. Opis składa się z różnych gatunków tekstu. Kompozycja, uważana dziś za nieforemną, bierze się wedle wyników badań między innymi ze sposobu dystrybucji książki jako subskrypcji, co kazało spełniać wytyczne dotyczące objętości ${ }^{3}$. Narrator relacjonuje w pierwszej osobie i można go utożsamiać z Twainem, pokazuje się jako naiwny, skłonny do przesady amerykański turysta, któremu wiele się nie udaje. Zatrudnia on zaufaną osobę, zwaną Mr. Harris, z którą może się w najlepsze kłócić. Prowadzi też nieustający dialog z przewodnikiem Baedekera, który wyszydza, a jednocześnie jest od niego zależny. Zależność tę ukazuje już konwencjonalna trasa podróży. Trasa Genewa-Lucerna (lub na odwrót) przyjęła się już od stu lat wśród podróżujących przez Alpy ${ }^{4}$.

W trakcie wejścia na Rigi, modną w XIX wieku górę niedaleko Lucerny, Twain kieruje ostrze satyry na pewien nieodzowny rytuał pielęgnowany przez nobliwą międzynarodową klientelę. O wschodzie słońca widok świata Alp z tego miejsca przedstawia się szczególnie spektakularnie. Aby wzmocnić to wrażenie, zbudowano wysokie rusztowanie z drewna, na którym goście hotelowi zbierają się o świcie prowizorycznie opatuleni w wełniane koce, czyli „w stroju Indian”. Od 1871 roku na Rigi prowadzi pierwsza kolejka górska Europy. Jednak Twain i Mr. Harris chcą wejść na szczyt pieszo, co wedle Baedekera powinno zająć 3 godziny i 15 minut. Potrzebują na to trzech dni i udaje im się cztery razy nie zdążyć na wschód słońca. W połowie wysokości w małej gospodzie są zdecydowani ,solidnie nacieszyć się swoim pierwszym alpejskim wschodem słońca”, budzą się jednak dopiero krótko przed południem. Nie lepiej dzieje się nieco wyżej w hotelu; tym razem sen trwa do popołudnia. Trzeciego dnia, teraz na wierzchołku, wspinają się na rusztowanie akurat aby przeżyć jeszcze zachód słońca. Gdy następnego ranka budzi ich dźwięk rogu alpejskiego, narratorowi przebiega przez głowę następująca myśl: „Iluż to szczęśliwych ludzi w Europie, Azji, Ameryce i wszędzie śpi spokojnie w swoich łóżkach, nie musi wstawać i oglądać wschodu słońca na Rigi”. Amerykański duet jest szczęśliwy, że może tym razem patrzyć tylko z okna i zauważa zbyt późno, że wychodzi ono w kierunku wczorajszego zachodu słońca ${ }^{5}$.

${ }^{3}$ H. Breinig, Mark Twain. Eine Einführung in sein Werk, Darmstadt 2011, s. 16, 42 n. Zob. także J.A. Melton, Mark Twain, Travel Books, and Tourism, Tuscaloosa 2002; G. Camfield, The Oxford Companion to Mark Twain, Oxford 2003. Tramp Abroad jest rzadko uwzględniany w przeglądach literatury alpejskiej; jednocześnie w obszernej amerykańskiej literaturze odnoszącej się do Twaina nie poświęca się wiele uwagi alpejskiej części tej podróży.

4 J. Mathieu, Alpine Tourism: Refashioning a Model, [w:] Oxford Handbook of History of Tourism and Travel, red. E. Zuelow, K. James, [w druku].

5 M. Twain, Bummel durch Europa, [w:] idem, Gesammelte Werke in fünf Bänden, red. K.J. Popp, t. 3, München 1966, s. 826-840.

Góry - Literatura - Kultura 14, 2020

(C) for this edition by CNS 
Celem kpin Twaina stają się w Alpach na terenie Wallis i Savoy alpinizm naukowy i heroiczny. Z Zermatt na górę Riffel (gdzie od lat znajduje się hotel) organizuje on wysokogórską ekspedycję badawczą, zabierając 154 osoby, 51 zwierząt oraz olbrzymią ilość prowiantu i sprzętu. Powiązany linami i gotowy do wymarszu pochód mierzy ponad pół mili. Wedle Baedekera drogi, która powinna zająć trzy godziny, nie da się pomylić. Amerykaninowi udaje się to oczywiście i błądzi wraz z karawaną przez siedem dni ${ }^{6}$. W Chamonix poświęca się innym celom. W biurze naczelnego przewodnika górskiego można uzyskać potwierdzenie, że weszło się na najwyższy szczyt Alp Mont Blanc. Od chwili zdobycia tej góry minęło stulecie i setki ludzi już na niej były. Teraz właśnie przyszła kolej na numer 685 , który otrzymuje „cenny urzędowy dyplom” poświadczający rodzinie i potomkom, że był ,wystarczająco lekkomyślny”, aby zdobyć się na ten czyn. Na to Twain chce uzyskać od naczelnego przewodnika podobny dokument dla swojego przyjaciela będącego inwalidą, który tak bardzo chciałby zdobyć Mont Blanc. Naczelnik jednak odmawia mu „w sposób dość bezwstydny”, a także numer 685 uparcie odpiera ofertę kupna. W końcu nie po to nadstawiał karku?

Ostre pióro Twaina opisuje na całej trasie podróży wszystko, co się dzieje wokół ówczesnej turystyki: kult kijów alpejskich, na których wypala się wszystkie nazwy miejscowości; fantazyjne targi pamiątek, oczekujących zapłaty jodłujących pastuszków; szarotkę, wysławianą roślinę alpejską ${ }^{8}$. Turyści spalają swój tłuszcz. Bywają określani jako „horda” lub „błazny”, w oryginale amerykańskim: horde, fools 9 . Narratorowi najwyraźniej sprawia przyjemność parodiowanie stereotypowych rozmów między turystami, a szczególnie między swoimi ziomkami: „Jest Pan Amerykaninem, jak sądzę? Ja również”. Wtedy się zaczyna: „Na jakim statku Pan przypłynął?... Jak minął Panu rejs?... W jakim hotelu się Pan zatrzymał?... Był Pan już na Rigi?"10.

Przyrodę alpejską Twain raczej oszczędza, trzymając się konwencjonalnych reguł i określając ją, w zależności od sytuacji, jako „malowniczą”, „,majestatyczną" czy też używając innych przymiotników. W niektórych miejscach wartościowanie wzrasta aż do określenia ,tron bogów”. Jednak stanowisko narratora nie zawsze jest jednoznaczne. Kiedy Twain i Mr. Harris przekraczają przełęcz Gemmi, pozostawiając za sobą strefę wegetacji, przyroda staje się ,pustkowiem o ponurym wejrzeniu"11. Bardziej podoba mu się położona nisko przełęcz Brünig, „upstrzona uroczymi małymi châlets, tymi tak dziwnie zachwycającymi szwajcarskimi chatami"l2.

6 Ibidem, s. 920-947.

7 Ibidem, s. 984.

${ }^{8}$ Ibidem, na przykład s. 793 n., 830 n., 885, 1008.

9 Ibidem, s. 794, 983; M. Twain, A Tramp Abroad - Following the Equator - Other Travels, red. R. Blount, New York 2010, s. 158, 307.

${ }^{10}$ M. Twain, Bummel durch Europa, s. 818-826.

11 Ibidem, s. 876, 887.

12 Ibidem, s. 855. 
A jak postrzega amerykański travel writer miejscową ludność? W centrum jego uwagi stoją turyści, inne osoby pojawiają się tylko wyjątkowo. Zwracają uwagę wozacy, zazwyczaj pijani, jednak zdolni w tym stanie do kierowania swym zaprzęgiem w zawrotnym tempie przez najniebezpieczniejsze drogi górskie. Ponadto Twainowskie Alpy zaludniają przewodnicy górscy i piękne karczmarki ${ }^{13}$. Autor, który stworzył postacie urwisów Toma Sawyera i Huckleberry Finna, przygląda się dzieciom. W drodze do Zermatt spotyka gromadę bawiącą się w alpinizm: „Były powiązane sznurem, nosiły zabawkowe kije alpejskie oraz czekany i właśnie wspinały się na małą skromną kupę gnoju, zachowując przy tym ostrożność i uwagę, od których włosy stawały dęba"14. Górska uprawa roli zostaje wspomniana po to, aby zilustrować stromość krajobrazu (rolnik traci przy oraniu równowagę, co kończy się śmiertelnym upadkiem). Z toku narracji pewnej absurdalnej historii wynika stwierdzenie, że „Praszwajcar nie był wcale tym głupim dzikusem, jakim się go przedstawia”. Za to pewnemu Anglikowi Twain wkłada w usta następującą formułę pożegnalną: „No, jestem zadowolony. Zobaczyłem główne cechy szwajcarskiego krajobrazu — Mont Blanc i wole ruszamy, do domu!"'15.

\section{Nauka: Germaine Veyret-Verner, 1956-1971}

W innych czasach i z zupełnie innego punktu widzenia zajmowała się alpejską turystyką francuska geografka Germaine Veyret-Verner. Urodzona na krótko przed wybuchem I wojny światowej, spędziła młodość przede wszystkim w położonej w głębi Alp dolinie Maurienne. Potem pracowała przez krótki czas jako nauczycielka, a w 1949 roku, przedstawiwszy pracę o przemyśle w Alpach francuskich, objęła profesurę na Uniwersytecie w Grenoble, którą piastowała do śmierci w wieku sześćdziesięciu lat. Jej działalność badawcza i publikacje obracały się wokół czterech tematów, wszystkich związanych z górami: ludność, rozwój miast, turystyka i planowanie regionalne. Wraz ze swoim mężem Paulem Veyretem opublikowała w 1967 roku przeglądowe dzieło o Alpach przeznaczone dla laików, pod tytułem Au coeur de l'Europe, les Alpes. Było to także wyznanie uczynione tym górom w czasach, w których znaczenia nabierała Europejska Wspólnota Gospodarcza ${ }^{16}$. Piśmiennictwo geograficzne to wydajne źródło, jeśli chodzi o krytykę historii turystyki. Zajmuje się ono w sposób deskryptywny

13 Ibidem, na przykład s. 860, 883, 974 n., 982 n.

14 Ibidem, s. 973.

15 Ibidem, s. 954, 971 n., 1009. Chamonix znajduje się w Sabaudii, ale w literaturze podróżniczej do XX wieku często było przypisywane do Szwajcarii. Wole to powiększenie szyi spowodowane chorymi gruczołami tarczycy, często wywołane niedoborem jodu; podobno w Alpach częściej występujące niż gdzie indziej.

16 Zob. nekrologi F. Germain, Germaine Veyret-Verner, „La Montagne et Alpinisme” 94/95, 1973/1974, s. 178; i P. Veyret, Germaine Veyret-Verner 1913-1973, „Revue de géographie alpine” 62, 1974, s. 7-16. 
i normatywny turystyką w badanym regionie i w drugiej połowie XX wieku doznało wielkiego przeobrażenia. Dla lepszego zrozumienia Veyret-Verner warto przyjrzeć się najpierw temu kontekstowi.

Raoul Blanchard (1877-1965), założyciel Institut de géographie alpine w Grenoble, był jeszcze człowiekiem postępu. Jego zdaniem także w górach z ich „macoszą naturą" należy rozwijać rolnictwo i przemysł. W wydanym w 1956 roku tomie zamykającym jego obszerne dzieło dotyczące Alp Zachodnich turystyka tworzy poboczny przedmiot, który jednak zasługuje na wzmiankę: „Tak więc warto brać poważnie działalność turystyczną i traktować ją jako solidny element gospodarki alpejskiej, mimo otoczki słownej, która tej działalności nazbyt często towarzyszy”. Jest to zdaniem Blancharda „piękny ruch”, w szczególności nowoczesny ruch samochodowy świadczący o dobrobycie i wiodący masę turystów w Alpy ${ }^{17}$. Po przełomie ekologicznym około roku 1970 rzeczy zaczęły się przedstawiać inaczej. Teraz w geografii alpejskiej nie chodzi już o to, aby naturze przysporzyć możliwie dużo postępu, teraz natura musi być chroniona przed skutkami tegoż postępu. Największy sukces wśród publikacji tego rodzaju odniosło opracowanie niemieckiego geografa Wernera Bätzinga (ur. 1949). Ukazało się ono w 1984 roku pod tytułem Die Alpen. Naturbearbeitung und Umweltzerstörung i było w następnych dziesięcioleciach wielokrotnie wznawiane w zmienionej i rozszerzonej formie. Pierwotna wersja publikacji nie ma wielkiego mniemania o ruchu turystycznym. Wedle jej słów powoduje on jako masowy fenomen od około 1955 roku powstawanie „tworów wielkomiejskich” z ,zanieczyszczeniem środowiska jak w Berlinie”. Czytamy też, że tradycyjny obraz przestrzeni alpejskiej zmienił się „miejscami nie do poznania”. Gospodarujący w górach rolnicy giną „W tej powodzi ludzi” i są przez nią wchłaniani ${ }^{18}$.

Jaką pozycję zajmuje Germaine Veyret-Verner na tym polu naukowych i ideologicznych zmagań? Potencjał turystyczny odkryła jeszcze przed swoim nauczycielem Blanchardem. Wyraża to już w tytule artykuł z 1956 roku Le tourisme au secours de la montagne: l'exemple de Val-d'Isère (Turystyka spieszy górom z pomocą: przykład Val-d'Isère). Traktuje on o rozwijającym się sporcie zimowym, rozkwicie sportów narciarskich wraz z wyciągami narciarskimi i przetrasowanymi stokami, który nakręcany jest w wielkim stylu w wysoko położonych miejscowościach Savoyu. W pierwszej części artykułu ukazany zostaje regres i starzenie się ludności alpejskiej na tle potężnej emigracji trwającej aż do lat trzydziestych. W drugiej części zbadane zostały nowe procesy rozwoju turystyki oraz ich oddziaływanie na gospodarkę rolną i demografię, co prowadzi do wniosku o ,totalnym sukcesie" 19 . Veyret-Verner wychwala turystykę jesz-

17 R. Blanchard, Les Alpes Occidentales, t. 7. Essai d'une Synthèse, Grenoble 1956, s. 445463, oryg. wyd. francuskie: s. 452, 458.

18 W. Bätzing, Die Alpen. Naturbearbeitung und Umweltzerstörung. Eine ökologisch-geographische Untersuchung, Frankfurt a. M. 1984, s. 57-60; ostatnie wydanie książki ukazało się w 2015 roku.

${ }^{19}$ G. Veyret-Verner, Le tourisme au secours de la montagne: l'exemple de Val-d'Isère, „Revue de géographie alpine" 44, 1956, s. 37-56, oryg. wyd. francuskie: s. 37.

Góry - Literatura - Kultura 14, 2020

(C) for this edition by CNS 
cze w 1968 roku w artykule sprowadzającym jej ogólnoalpejskie i europejskie badania do krótkiego mianownika: Alpy są terenem dla sportu, czasu wolnego i zdrowia kontynentu. Dzięki turystyce stały się atrakcyjne dla imigracji i dla przemysłu, co wychodzi na dobre również rolnictwu ${ }^{20}$.

Jednak czasy się zmieniają, a profesorka już wcześniej poczyniła ambiwalentne doświadczenia. Jako ekspertka brała udział w turystycznym planowaniu regionalnym, stojąc przez jakiś czas w opozycji, i została usunięta z Comité d'Expansion régional. Jakie było tło tych wydarzeń, można się domyślić, czytając podstawowy artykuł z roku 1971: Aménager les Alpes: mythes et réalités (Planować Alpy: mity i rzeczywistość). Tutaj Veyret-Verner w sposób zdecydowany zajmuje stanowisko przeciw technokratycznej euforii związanej z turystyką, a za planowaniem w jej oczach „realistycznym i ludzkim”. Trzeba obnażyć mit o turystyce jako maszynie produkującej dobrobyt. Problematyczne w tej gałęzi gospodarki są jej punktowy charakter ograniczający się do nielicznych uprzywilejowanych stacji, mocna sezonowość oraz fakt, że gałąź ta jest coraz bardziej kontrolowana przez wielkie zagraniczne koncerny. Veyret-Verner broni lokalnej władzy decyzyjnej i ostrzega przed bezsensownymi i niszczycielskimi przygodami. Jej zdaniem należy zachować wypracowaną w długiej historii „równowagę między mądrością i doświadczeniem” (,équilibre de sagesse et d'expérience”). Respektować przeszłość, ale zwalczać nostalgię za przeszłością - tak brzmi teraz jej dewiza ${ }^{21}$.

\section{Polityka: Alexander Scheutz, 2009-2020}

Alexander Scheutz, od 2009 roku burmistrz Hallstatt w austriackim Salzkammergut, ze względu na piastowany urząd zajmuje się kwitnącą turystyką, odbieraną przez niektórych jako regularna inwazja na liczącą 750 mieszkańców miejscowość. Ostatnimi czasy musi również regularnie rozmawiać z mediami. Na początku 2019 roku z „Oberösterreichische Nachrichten”:

Rocznie odwiedza Hallstatt do miliona gości, którzy przyjeżdżają na jeden dzień. Jak wielu wytrzyma ta miejscowość? - z mojego punktu widzenia powinno to być o 25 do $30 \%$ mniej. Przy czym ostrzegam przed generalnym oczernianiem jednodniowych turystów. Wielu mieszkańcom Hallstatt turystyka autokarowa przynosi zyski. W naszej gminie nie ma umierania gospodarzy jak w całej Górnej Austrii. U nas gospodarze kupują nieruchomości.

Dziennikarz dopytuje: „Czy nie byłoby najlepiej żądać od jednodniowych gości opłaty za wstęp do Hallstatt?”.

${ }^{20}$ G. Veyret-Verner, Les Alpes et l'Europe, „Revue de géographie alpine” 56, 1968, s. 5-41.

${ }^{21}$ G. Veyret-Verner, Aménager les Alpes: mythes et réalités, „Revue de géographie alpine” 59, 1971, za: s. 5 n., 14-16, 17-19, 23 n., 28-43. 
Nie przekonuje mnie ta propozycja. Nie chcemy żyć w skansenie. Nie chciałbym też, aby wszyscy mieszkańcy Hallstatt i wszyscy uczniowie Wyższej Szkoły Technicznej musieli każdego dnia przechodzić przez bramki obrotowe. Poza tym jako socjaldemokrata nie mogę zgodzić się, aby to, kto do nas przyjeżdża, a kto nie, stało się kwestią pieniędzy ${ }^{22}$.

Mała miejscowość nad Hallstätter See może się pochwalić bardzo długą historią górnictwa soli. W XIX wieku turystyka zaczęła zastępować kopalnie soli. Po II wojnie światowej przybrała one jeszcze na sile, co jednak z początku nie przyniosło publicznych korzyści. Scheutz chętnie eksponuje w rozmowach z dziennikarzami fakt, że Hallstatt było zadłużone i dopiero w ostatnich latach wypracowało nadwyżki w budżecie gminnym. Ale globalna kariera tej miejscowości zaczęła się już wcześniej. Od 1997 roku region Hallstatt-Dachstein/ Salzkammergut jest częścią światowego dziedzictwa UNESCO. Wedle opinii ekspertów chodzi tu o „niezwykły przykład naturalnego krajobrazu wielkiej urody i o znaczeniu naukowym". Jednocześnie przez tysiącletnią tradycję wydobywania soli daje on świadectwo elementarnej kultury 23 .

Boom rozpoczyna się na dobre w XXI wieku. Zespół filmowców kręci południowokoreański serial telewizyjny Spring Waltz (Wiosenny walc), którego akcja rozgrywa się po części w Salzburgu i Hallstatt. Tematem filmu jest pierwsza miłość i tęsknota za idealnym miejscem ucieczki przed surową rzeczywistością. Niedługo później koncern China Minmetals rozpoczyna w południowochińskiej prowincji Guangdong budowę kosztującego miliony osiedla mieszkaniowego, którego centrum jest kopią Hallstatt. Jako burmistrz Scheutz jedzie w 2012 roku na ceremonię otwarcia i podpisuje porozumienia o wymianie kulturalnej. Wszystko to wywołuje hałas medialny oraz intensywny wzrost liczby azjatyckich turystów. Uwagę w mediach społecznościowych wzmagają niezliczone zdjęcia i selfie. Biura turystyczne organizujące wycieczki autobusowe szykują pakiet podróży po Austrii: Innsbruck, Salzburg, Hallstatt, Wiedeń. Pobyt w Hallstatt to zwykle tylko spacer po miejscowości, zakup pamiątek i sesja zdjęciowa ${ }^{24}$.

Przeciwko temu narodził się opór. W 2015 roku w wyborach do rady gminy biorą udział kandydaci z listy Obywatele dla Hallstatt, która otrzymała od razu prawie 30\% głosów. Jej hasło wyborcze brzmi: „Turystyka z umiarem i celem”. Miejscowość powinna znów stać się miejscem, w którym chce się żyć. Skarg

${ }^{22}$ E. Brandner, Hallstatt steigt auf die Notbremse: Zahl der Touristenbusse wird limitiert, „Oberösterreich Nachrichten” 29.01.2019, https://www.nachrichten.at/oberoesterreich/hallstatt-steigtauf-die-notbremse-zahl-der-touristenbusse-wird-limitiert;art4,3096533 (dostęp: 9.06.2021).

23 UNESCO, Lista Światowego Dziedzictwa, Hallstatt-Dachstein/Salzkammergut, kryterium IV, online (w oryginale w języku angielskim); zob. też T. Hellmuth, Die „,Erfindung “ des Salzkammerguts. Imaginationen alpiner Räume und ihre gesellschaftliche Funktionen, [w:] Die Alpen! Zur europäischen Wahrnehmungsgeschichte seit der Renaissance / Les Alpes! Pour une histoire de la perception européenne depuis la Renaissance, red. J. Mathieu, S. Boscani Leoni, Bern 2005, s. 349-363.

24 E. Brandner, op. cit. 
jest wiele: hałas i inne emisje, zawyżone ceny, przepełnione lokale, ciągła obserwacja: także w domu, ogrodzie i na balkonie, fotografowanie i kręcenie filmów, nawet za pomocą dronów. Zdarzają się fizyczne przekroczenia sfery prywatnej. A mieszkańcy mają przecież prawo do normalnego życia. „Kiedy ma tu miejsce pogrzeb" dowiaduje się dziennikarz od jednego z opozycjonistów, ,jest on filmowany przez tysiące ludzi. Kiedy kapela kończy marsz pogrzebowy, rozlega się aplauz. Na cmentarzu turyści pozują do zdjęć. Nie ma już miejsca na żałobę mieszkańców". Lista obywatelska zwraca się przede wszystkim przeciwko turystom przybywającym w autokarach, którzy szybko się pojawiają i znów znikają, a nie przeciwko dłużej przebywającym gościom. W tym jest zgoda $\mathrm{z}$ hotelarzami. Ci skarżą się jednak, że turystyczny image miejscowości został nadszarpnięty ${ }^{25}$.

Burmistrz Scheutz chce opanować problem autobusów turystycznych, tworząc koncepcję ruchu. Jej wypracowanie zleca fachowcom i dochodzi do „procesu udziału obywateli”. Firma Kohl\&Partner wypracowała „Overtourism-Analyse-Toll" mający ocenić i poglądowo zwizualizować utrudnienia dla mieszkańców i gości oraz obciążenie infrastruktury i przyrody. W maju 2018 roku firma organizuje w Hallstatt publiczną debatę o nastawieniu mieszkańców do turystyki, stawiając pytanie: „Czynnik zakłócający »gość« czy raczej wartość dodana dzięki inteligentnym koncepcjom przyjazdów?". W czerwcu odbywa się ,wieczór obywatelski dla wypracowania nowej koncepcji ruchu i turystyki”. Po zabraniu głosu przez Scheutza i ekspertów mogą przemówić mieszkańcy Hallstatt. Mogą wyrazić życzenia, a w rubryce „Proszę nie” podać, czego należy unikać. Większość wpisów jest krytyczna: „Proszę już nie wyprzedawać miasta za bezcen... drony... taniocha... pytania, czy tu mieszkamy/żyjemy/jesteśmy prawdziwi”. Znalazł się jednak też ktoś, kto nie chciał oskarżać całej turystyki ${ }^{26}$.

Nowa koncepcja ruchu po części opiera się na środkach przedsięwziętych niedawno w mieście Salzburg. Chodzi o ograniczenie, przekierowanie i reglamentowanie autobusów turystycznych: wjazd do terminala tylko między godziną 8 a 17; obligatoryjny zakup biletu w systemie slot; maksymalnie dwanaście wjazdów i wyjazdów na godzinę; minimalny czas postoju dwie i pół godziny; podwyższenie cen. Alexander Scheutz cieszy się, że koncepcja w lutym 2019 roku została jednogłośnie przyjęta przez Radę Gminy Hallstatt i że może rozpocząć jej realizację. Nieco później pandemia COVID-19 pokazała, jak podatny na kryzysy jest ten rodzaj turystyki. Tymczasem tablice, które kazał umieścić w miejscowości, informują turystów w języku chińskim i angielskim:

${ }^{25}$ M. Schulze Berndt, Hallstatt wäre so schön - wenn die Touristen nicht wären, „Augsburger Allgemeine" 13.03.2019, https://www.augsburger-allgemeine.de/panorama/OesterreichHallstatt-waere-so-schoen-wenn-die-Touristen-nicht-waeren-id53764341.html (dostęp: 9.06.2021); E. Brandner, op. cit.

${ }^{26}$ Firma Business Konsens 26.06.2018, Erster Bürgerabend zur Erarbeitung eines neuen Verkehrs- und Tourismuskonzept (Pierwszy wieczór obywatelski poświęcony opracowaniu nowej koncepcji transportu i turystyki), strona internetowa Hallstatt.

Góry - Literatura - Kultura 14, 2020

(C) for this edition by CNS 
Hallstatt nie jest muzeum. Proszę w czasie Państwa pobytu mieć wzgląd na ludzi, którzy tu mieszkają. Proszę nie wchodzić na teren prywatny, ściszyć głos i wyrzucać śmieci do kosza. Dziękujemy za zrozumienie ${ }^{27}$.

\section{Podsumowanie}

Czy Alpy są dla turystyki? W trzech ujęciach z różnych czasów i regionów alpejskich usłyszeliśmy przede wszystkim głosy pisarza, profesorki i burmistrza. Pod koniec XIX wieku Mark Twain w satyryczny sposób ukazuje konwencje i wzorce myślowe turystyki elit na klasycznej trasie między Lucerną a Genewą. Dlaczego tak ważne jest ujrzenie wschodu słońca na Rigi? Dlaczego trzeba wspiąć się 4800 metrów powyżej poziomu morza na Mont Blanc? Germaine Veyret-Verner, geografka z Grenoble, francuskiego miasta w Alpach, podczas powojennego boomu zmaga się z oceną turystyki, która teraz zyskała inny liczbowo wymiar oraz została zdominowana przez nowy sport zimowy. Z począt$\mathrm{ku}$ widzi $\mathrm{w}$ niej nadarzającą się szansę $\mathrm{w}$ walce $\mathrm{z}$ demograficznym upadkiem górskich wsi, potem nabiera sceptycyzmu wobec ślepej technokratycznej euforii. O wypracowanie pewnej linii działania stara się na płaszczyźnie politycznej także Alexander Scheutz na początku XXI wieku; powodem jest przede wszystkim nadmiar autokarów turystycznych w austriackim Hallstatt. Jako burmistrz musi znaleźć równowagę między turystyką, z której wielu żyje, a jej skutkami dla mieszkańców, na które wielu się skarży.

Ten wybór głosów nie odzwierciedla turystyki alpejskiej w jej licznych historycznych i regionalnych przejawach. Jeśli pominąć woźniców i przewodników u Twaina, nie usłyszeliśmy na przykład nic o rzemieślnikach, kupcach czy personelu. Poza tym szeroko pojęta ludność przestrzeni alpejskiej, z początku żyjąca przede wszystkim z rolnictwa, później poświęcająca się innym działaniom, w ogóle nie została dopuszczona do głosu. Jak moglibyśmy poprawić przegląd, uwzględniając ten aspekt alpejskiego rozwoju?

W ostatnich dziesięcioleciach historia turystyki stała się dziedziną naukową i uległa dywersyfikacji. Nie chodzi już przede wszystkim o ekonomiczne historie sukcesu. Oglądowi poddane zostają też wymiary kulturowe, kryzysy oraz inne zjawiska $^{28}$. Są to jednak dopiero początki historii krytyki. Podobnie jak w tym przyczynku można by spróbować opracować i zestawić aspekty literackie, historyczne i polityczne. Z licznych możliwych podejść chcielibyśmy podkreślić:

1. Historia literatury. W swoich studiach dotyczących literackiego postrzegania turystyki alpejskiej w XIX i XX wieku Wolfgang Hackl bada wybór niemiec-

${ }^{27}$ H. Kazim, Warum so viele Chinesen nach Hallstatt kommen, „Der Spiegel” 20.10.2018, https://www.spiegel.de/reise/europa/hallstatt-in-oesterreich-warum-kommen-so-viele-touristenaus-china-a-1233291.html (dostęp: 9.06.2021) (zdjęcia).

28 Jak rozwijał się ten temat, można zobaczyć w „Journal of Tourism History” (od 2009). 
kojęzycznych mediów. Satyry, takie jak Marka Twaina, są w jego opracowaniu dobrze reprezentowane, wystarczy wspomnieć teksty ukazujące się od 1896 roku w czasopiśmie,,Simplizissimus" czy produkowanąjako serialtelewizyjny orazwwer sji książkowej Piefke-Saga wczesnych lat dziewięćdziesiątych XX wieku. Bywało, że satyry wywoływały gwałtowne reakcje i mogły mocno dotknąć. Hackl przytacza przypadek nauczyciela, który został za to karnie przeniesiony z Tyrolu na Morawy ${ }^{29}$. Clà Riatsch zajmuje się w pewnym artykule stylizacjami nieudanych dialogów między tubylcami a turystami w romańskiej literaturze Graubünden. Turysta mówi do chłopa ostrzącego swoją kosę: „Pięknie!”, na co otrzymuje odpowiedź „Üna merda schön!” (G... tam pięknie!). Badane fragmenty zaliczają się do różnych form literackich i wymagają uwzględnienia specyficznych tradycji gatunku. Często krytyka turystyki miesza się z ogólną krytyką modernizacji ${ }^{30}$.

2. Historia wiedzy. Od początków ,turystyki masowej” w czasie powojennym mamy do czynienia z wieloma klasycznymi tekstami krytyki turystyki, które można zaliczyć do naukowych w szerokim rozumieniu. Wymieniane są często publikacje niemieckiego eseisty Hansa Magnusa von Enzensbergera oraz brytyjskiego socjologa Johna Urry. Do obszaru alpejskiego odnoszą się książki szwajcarskiego ekonomisty i ekologa Josta Krippendorfa, przede wszystkim Alpsegen-Alptraum z 1986 roku $^{31}$. W związku z rosnącym akademickim charakterem tej gałęzi gospodarki w późnym XX wieku ukazało się szerokie spektrum literatury dotyczącej turystyki „łagodnej”, „,bliskiej natury”, „zrównoważonej” i „fair”. Być może można zaliczyć do krytyki nawet techniczne podejście związane z zarządzaniem (jak wspomniany w wypadku Hallstatt „Overtourism-Analyse-Tool") $)^{32}$. Od opracowania historycznego oczekiwałoby się w każdym razie przejścia od wąskiej historii nauki do szerokiej historii wiedzy. Nie chodzi więc głównie o to, aby na nowo badać The Tourist Gaze Johna Urry'ego w aspekcie wpływu naukowego, lecz raczej o przebadanie jego roli w ogólnym dyskursie społecznym ${ }^{33}$.

3. Historia polityczna. Krytyka szczególnego rodzaju może przyjść w czasach kryzysu. Pod naciskiem ludności władze austriackie wydawały w czasie I wojny światowej i później urzędowe zakazy w odniesieniu do turystyki. Zdarzały się

29 W. Hackl, Eingeborene im Paradies. Die literarische Wahrnehmung des alpinen Tourismus im 19. und 20. Jahrhundert, Tübingen 2004, s. 97-115, 116-117, 167-173; dla Niemców Piefke to w języku austriackim przede wszystkim obraźliwe określenie.

30 C. Riatsch, Stilizzazioni letterarie di un contro-discorso alpino. Alcuni esempi retoromanci, [w:] Die Alpen! Zur europäischen..., s. 419-427.

$31 \mathrm{Na}$ temat Enzensbergera i Urry'ego zob. M. Backes, Konjunkturen der Tourismuskritik, „Kurswechsel” 2005, nr 2, s. 13-21; J. Krippendorf, Alpsegen-Alptraum. Für eine Tourismus-Entwicklung im Einklang mit Mensch und Natur, Bern 1986.

32 D. Siegrist, S. Gessner, L. Ketterer Bonnelame, Naturnaher Tourismus. Qualitätsstandards für sanftes Reisen in den Alpen, Bern 2015.

33 D. Chassé Speich, D. Gugerli, Wissensgeschichte. Eine Standortbestimmung, „Traverse” 2012, nr 1 , s. 85-100. 
też protesty głodowe i wtargnięcia do hoteli ${ }^{34}$. Podczas gdy w tych przypadkach chodziło o wyładowanie lokalnej wściekłości na uprzywilejowanych „obcych”, ochrona przyrody i środowiska stały się na długo ważnym czynnikiem politycznym. Kiedy około 1900 roku wybudowano w Szwajcarii kolej na Jungfrau i przemyśliwano także nad koleją na Matterhorn, narodził się opór wśród nizinnych kręgów wykształconego mieszczaństwa i alpinistów. Chodziło o „czystość naszych gór" i o kwestię, czy Matterhorn należy tylko do bogatych Anglików, nie zaś do wszystkich Szwajcarów ${ }^{35}$. Wraz z przełomem ekologicznym około 1970 roku krytyka stała się intensywniejsza i bardziej zasadnicza, a najbardziej prominentnym jej wyrazicielem była CIPRA (Commission Internationale pour la Protection des Alpes). Ta pozarządowa organizacja dała impuls do podpisania w 1991 roku międzypaństwowej konwencji alpejskiej uzupełnionej później o „protokół turystyczny”36.

Podsumowując, należy podkreślić, że historia krytyki turystyki w Alpach mogłaby być przedsięwzięciem obszernym i wielowątkowym. Generalnie należy wskazać na pewną okoliczność podkreślaną już w 1971 roku przez Germaine Veyret-Verner: w porównaniu z wieloma górami świata, na przykład amerykańskimi Rocky-Mountains, Alpy są wcześnie i stosunkowo gęsto zaludnionym obszarem górskim ${ }^{37}$. Tutaj turystyka rozgrywa się więc w przestrzeni kulturowej, która jednak ze względu różnicę zagęszczenia wobec nizin od XVIII stulecia jest przez wielu Europejczyków postrzegana przede wszystkim jako przestrzeń natury. Do tego dochodzi, że turystyka alpejska jest bardzo nierówno podzielona. Naprzeciw stosunkowo niewielu miejscowości o wysokim natężeniu ruchu turystycznego stoją liczne miejscowości o małym natężeniu. Nie jest jasne, ile miejsc pracy obejmuje alpejski przemysł turystyczny w całości. Jeśli uwzględnić poszczególne dane, to nie należy przeceniać jego znaczenia ${ }^{38}$. Niemniej jednak jest on często przedstawiany jako niemający alternatywy nawet $\mathrm{w}$ miejscach, w których go prawie nie ma. Mamy tu do czynienia z gałęzią gospodarki, która opinię publiczną stawia wobec ponadproporcjonalnych wymagań. Krytyczna historia krytyki turystyki powinna się zająć także tą roszczeniową postawą.

Z języka niemieckiego przetożyła Monika Witt

34 R. Sandgruber, Die Entstehung der österreichischen Tourismusregionen, [w:] Tourismus und Entwicklung im Alpenraum, 18.-20. Jahrhundert, red. A. Leonhardi, H. Heiss, Innsbruck 2003, s. 201-226.

35 J. Mathieu, Die Alpen. Raum - Kultur - Geschichte, Stuttgart 2015, s. 143, 202.

36 Ibidem, s. 198-201.

37 G. Veyret-Verner, Aménager les Alpes, s. 34.

38 Bätzing wymienia około 15\% w okresie 1991-2011 (W. Bätzing, Lebensraum im Herzen Europas. Zwei Jahrzehnte Alpenkonvention und Perspektiven für die nächsten zwanzig Jahre, „werk, bauen + wohnen” 2011, nr 9, s. 9). 